\title{
Marine Diatoms Grown in Chemostats under Silicate or Ammonium Limitation. III. Cellular Chemical Composition and Morphology of Chaetoceros debilis, Skeletonema costatum, and Thalassiosira gravida*
}

\author{
P.J. Harrison, H.L. Conway *", R.W. Holmes"** and C.O. Devis**** \\ Depertment of Oceanography, Untventty of Washington; Seattle, Washington, USA
}

\begin{abstract}
Three marine diatoms, Skeletonema costatum, Chaetoceros debilis, and Thalassiosira gravida were grown under no limitation and ammonium or silicate limitation or starvation. Changes in cell morphology were documented with photomicrographs of ammonium and silicate-limited and non-limited cells, and correlated with observed changes in chemical composition. Cultures grown under sllicate starvation or limitation showed an increase in particulate carbon, nitrogen and phosphorus and chlorophyll a per unit cell volume compared to non-limited cells; particulate silica per cell volume decreased. Si-starved cells were different from Si-limited cells in that the former contained more particulate carbon and silica per ceil volume. The most sensitive indicator of silicate Iimltation or starvation was the ratio c:si, being 3 to 5 times higher than the values for non-limited cells. The ratios Si:chlorophyll a and $S: P$ were lower and N:Si was higher than non-limited cells by a factor of 2 to 3. The other ratios, C:N, C:P, C:Chlorophyll a, N:chlorophyll a, P:chlorophyll a and $\mathrm{N}: \mathrm{P}$ were considered not to be sensitive indlcators of silicate limitation or starvation. Chlorophyll $a$, and particulate nitrogen per unit cell volume decreased under ammonium limitation and starvation. NH4-starved cells contalned more chlorophyll a, carbon, nitrogen, silica, and phosphorus per cell volume than $\mathrm{NH}_{4}-1$ imited cells. N:Si was the most sensitive ratio to ammonium limitation or starvation, belng 2 to 3 times lower than non-limited cells. Si:chlorophyll a, P:chlorophyll a and $\mathrm{N}: \mathrm{P}$ were less sensitive, while the ratios $\mathrm{C}: \mathrm{N}, \mathrm{C}$ :chlorophyll $a, N$ :chlorophylla, $\mathrm{C}: \mathrm{S} 1, \mathrm{C}: \mathrm{P}$ and $\mathrm{S} 1: \mathrm{P}$ were the least sensitive. Limited cells had less of the limiting nutrient per unit cell volume than starved cells and more of the non-limiting nutrients (1.e., silica and phosphorus for $\mathrm{NH}_{4}$-limited cells). Th1s suggests that nutrient-limited cells rather than nutrient-starved cells should be used along with non-limited cells to measure the full range of potential change in cellular chemical composition for one specles under nutrient limitation.
\end{abstract}

\section{Introduction}

Phytoplankton growth requires the assimilation of inorganic nutrients from the water in which they are growing. GeneralIy, it is considered that these nutri-

*Contribution No. 943 from the Department of Oceanography, Untversity of Washington, Seattle, Washington 98195, USA.

**Present address: Radlological and Environmental Research Division, Argonne National Laboratory, Argonne, Ill1nots 60439, USA.

***Present address: Department of Marine Sciences, University of Californta, Santa Barbara, Callfornia 93106, USA.

****Present address: Great Lakes Research Div1sion, The Untversity of Michigan, Ann Arbor, M1chlgan 48109, USA. ents are withdrawn from the water in the proportions required for growth (Redfield et al., 1963). Further studies have shown that the nutrient uptake ratio or cellular chemical composition can be altered by: biological factors such as cell size (Paasche, 1973b) and age of culture (Pugh, 1975); physical factors such as light (intensity and photoperiod, Collos and Lewin, 1976; Davis, 1976) and temperature (Jørgensen, 1968; Harrison, 1974); chemical factors such as salinity (Pugh, 1975) source of nitrogen (nitrate or ammontum, Strickland et al., 1969) and nutrient limitation. This study is concerned entirely with the latter factor.

Much of the early work on chemical composition of marine phytoplankton began with the elements nitrogen and phos- 
phorus because it was thought that these two elements were most likely to limit phytoplankton growth in the natural environment. Early studies by Ketchum and Redfield (1949) showed that deficiencies of nitrogen or phosphorus in culture medium could decrease the $\mathrm{N}: \mathrm{P}$ ratio in chlorella pyrenoidosa by a factor of 2 for nitrogen deflclency and increase the ratio by a factor of 5 for phosphorus deficlency.

Batch cultures can be used to measure the chemical composition of logarithmically growing (non-limited) cells and starved cells, which are assumed to represent the extremes in the possible degrees of nutrient limitation. However, at intermediate degrees of limitation, and at lower concentrations of the limiting nutrient, the chemical environment changes so quickly that the degree of limitation can never be precisely known. Some workers (K11ham, 1975; Paasche, 1975) have used very low cell concentrations at low substrate concentrations so that the change in the substrate concentration would be slower. However, it is difficult to conduct chemical composition measurements at these low cell densities.

This problem in using batch cultures can be overcome through the use of continuous culture techniques, where the culture can be maintained at steady state at a specific growth rate and a specific degree of nutrient limitation. Changes in chemical composition of marine phytoplankton in continuous culture have been studied for various limiting nutrlents including nitrogen limitation (Caperon and Meyer, 1972; Thomas and Dodson, 1972; Conway, 1974; Eppley and Renger, 1974), phosphorus limitation (Fuhs, 1969; Fuhs et al., 1972; Droop, 1974; Perry, 1976), and silicate limitation (Paasche, 1973a; Davis, 1976; Harrison et al., 1976).

In the above studies, l1ttle attempt has been made to correlate the morphological changes that accompany the changes in chemical composition. Only Paasche (1973a) has documented the morphological changes that occur in continuous culture and a few studies have been conducted on starved cells grown in batch culture (Braruud, 1948; Holmes, 1966). Paasche's photomicrographs show extensive modifications in the frustule of Thalassiosira pseudonana when $1 t$ was grown under silicate limitation.

This paper presents data on the cellular chemical composition and morphology of three marine diatoms that were grown in chemostats under silicate or ammonium limitation and semi-continuously under unlimited and nutrient-starved conditions. The nutrient uptake kinetics of these three species will be presented in a subsequent paper (Conway and Harrison, 1977).

\section{Materials and Methods}

Three marine centr1c diatoms were used in this study. The source of skeletonema costatum has been previously described (Davis et al., 1973). Chaetoceros debilis Cleve was isolated at Friday Harbor, Washington, in 1970 by Dr. J. Lewin (University of Washington). Thalassiosira gravida Cleve was obtalned from the University of California culture collection, Santa Barbara (USA); it originated formerly from the Scripps Institute of Oceanography culture collection.

The chemostat system was the same as that described previously (Davis et al., 1973; Conway et al., 1976), except that the lighting system was changed. The new system consisted of three, $110 \mathrm{~W}$, daylight, fluorescent bulbs held in a parabolic reflector. A sheet of blue Plexiglas (No. 2069, Rohm and Haas) $0.3 \mathrm{~cm}$ thick, was used to modify the spectrum and make it comparable to $5 \mathrm{~m}$ underwater light for coastal conditions (described as Jerlov type 3 in Holmes, 1957). Continuous light was used and the intensity was $0.081 \mathrm{y} / \mathrm{min}$.

The cultures were grown at $180^{\circ} \mathrm{C}$ in artificlal seawater (Davis et al., 1973). Nutrients and vitamins were added in the proportions of medium $f$ (Guillard and Ryther, 1962). The concentration of the limiting nutrient was about 8 to $10 \mu \mathrm{g}-$ at/1-1 in the inflow medium, and the other nutrients, trace metals and vitamins were considered to be saturating at approximately $f / 50$ levels.

The dilution rates for the nutrientIImited cultures were chosen from the region where there was little or no change in effluent substrate concentration over a range of dilution rates (defined as region 2, Harrison et al., 1976). It was felt that dilution rates from this region (generally $D \sim 1 / 3$ to $1 / 2$ /max) produced representative nutrient-limited cultures. Thalassiosira gravida grows more slowly than the other two specles and, therefore, it was grown at a lower dilution rate in order to obtain chemical composition data from a comparable region of the growth curve (region 2). UnIimited cells were obtalned from semicontinuous cultures (daily dilutions of batch cultures) in which cells were growing logartthmically and nutrients were saturating. Starved celis were obtained by allowing these semi-continuous cultures of logarithmically growlng cells to deplete the limiting nutrient (ammo- 
nium or silicate) in the medium while other nutrients were maintalned at saturating levels. The starvation period lasted $72 \mathrm{~h}$. At the end of this period the cells were still capable of taking up the limiting nutrient, indicating that they were still viable (Conway and Harrison, 1977). Recognition of viablelooking cells was facllitated by counting live, rather than preserved samples.

When cultures growing in the chemostat reached steady state, which was determined by no trend in cell numbers or fluorescence over several days, effluent nutrient concentrations, cell numbers and volumes were measured. Samples for particulate carbon, nitrogen and silica were obtained by filtering about $100 \mathrm{ml}$ of the effluent culture.

Nutrient analyses, fluorescence measurements and cell counting techniques were the same as in previous studies (Davis et al.,1973). The chlorophyll a determination was similar to the SCOR UNESCO method (Blasco, 1973); the main modification was that the glass-fiber filters were put directly into 908 acetone and allowed to extract in the dark in a refrigerator for 3 to $20 \mathrm{~h}$. Particulate sillca (PSi) was analyzed by the sodium fusion procedure of Busby and Lewin (1967). Particulate nitrogen (PN) and carbon (PC) were analyzed with a Carlo Erba CHN analyzer (Model 1100).

Cell volumes were calculated from microscopical measurements of cell diameter and length. The cells were taken to be cylindrical in shape, except for Chaetoceros debilis which was assumed to be elliptical with semi-axes of $a$ and $b=$ $3 / 4$ a. The mean cell volume reported is from a measurement of 50 cells.

Photomicrographs were taken of live material under phase contrast using a Zelss compound inicroscope.

Estimates of particulate nitrogen and silica were made by direct analysis and by mass balance (inflow minus outflow nutrient concentrations). Direct analyses were found to be more variable (Harrison et al., 1976) and therefore particulate silica, nitrogen and phosphorus were measured by mass balance in this study. Higher varlability in the direct analysis was also observed by Caperon and Meyer (1972). The mass balance method assumes that a negligible amount of the lnorganic nutrient in the inflow medium is converted into dissolved organic compounds.

\section{Reaults}

\section{Cell Morphology}

Distinct differences in cell morphology of a specles resulted from growth under silicate-limited (Si-limited), ammoniumlimited ( $\mathrm{NH}_{4}$-limited), and non-limited nutrient conditions. These differences for the three species are shown in the photomicrographs (F1g. 1). The morphological changes in starved cells were not as striking as in limited cells, but otherwise they were similar. Photomicrographs of starved cells have not been included.

A comparison of St-limited, nonlimited, and $\mathrm{NH}_{4}$-limited cells of skeletonema costatum is made in Fig. 1A, B and $C$, respectively. The number of cells/ chaln was generally greater than 10 for non-limited cells, greater than 6 for $\mathrm{NH}_{4}$-limited cells and less than 4 for Si-limited cells. The length of the connecting rods between cells was normal (3 $\mathrm{mm}$ ) for non-limited and NH4-limited cells and almost zero for si-limited cells. Many Si-limited cells appeared to have more or larger chromatophores than non-limited or $\mathrm{NH}_{4}$-limited cells. The largest cell vacuole was observed for $\mathrm{NH}_{4}$-limited cells. $\mathrm{S} 1-$ and $\mathrm{NH}_{4}$-limited cells were usually very long and narrow, typically about $12 \mu \mathrm{m} \times 3 \mu \mathrm{m}$.

The changes in morphology of Chaetoceros debilis are shown in Fig. 1D, E and F. Agaln the number of cells/chain was less ( $\sim 4)$ under silicate limitation than under no limitation $(\sim 10)$ or ammonium limitation $(\sim 10)$. The length of the projectIng setae was normal under no limitation and ammonium limitation, but setae were shorter or absent under silicate limitation. Usually there were two chromatophores rather than one, under silicate limitation. The size of the vacuole in relation to the rest of the cell was difficult to estimate.

Changes in the morphology of thalassiosira gravida were similar to the other two species (Fig. 1G, H and I). The number of cells/chain was lowest under silicate limitation (<4); frequently a large portion of the population appeared as single cells. The width of the cell was usually less than the length under silicate limitation, whereas the width was greater than the length under no limitation and a mixture of cell widths occurred under ammonium limitation (Table 1). Si-limited cells had more chromatophores than non-limited and $\mathrm{NH}_{4}$-limited cells. The frustule appeared to be irregular and bumpy in $\mathrm{Si}^{-}$and $\mathrm{NH}_{4}-$ limited cells. The size of the vacuole was smallest in Si-limited cells and greatest in $\mathrm{NH}_{4}$-limited cells. The mucilagenous thread connecting the si-limited cells was generally shorter and thinner in comparison to non-limited and $\mathrm{NH}_{4}$-limited cells. 


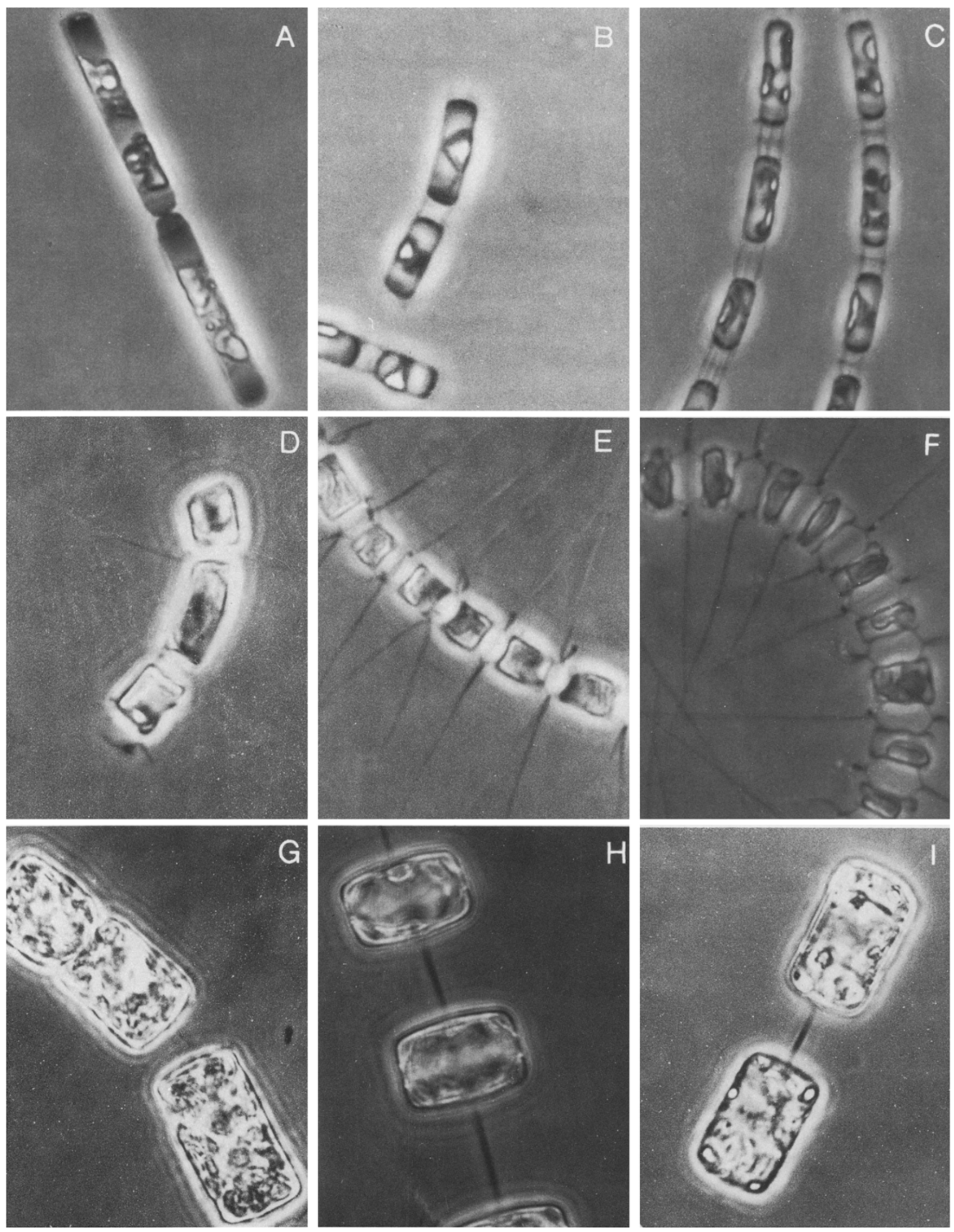


Table 1. Cell volume, surface area, and plgment ratios of 3 marine diatoms grown under different nutrient ilmitations

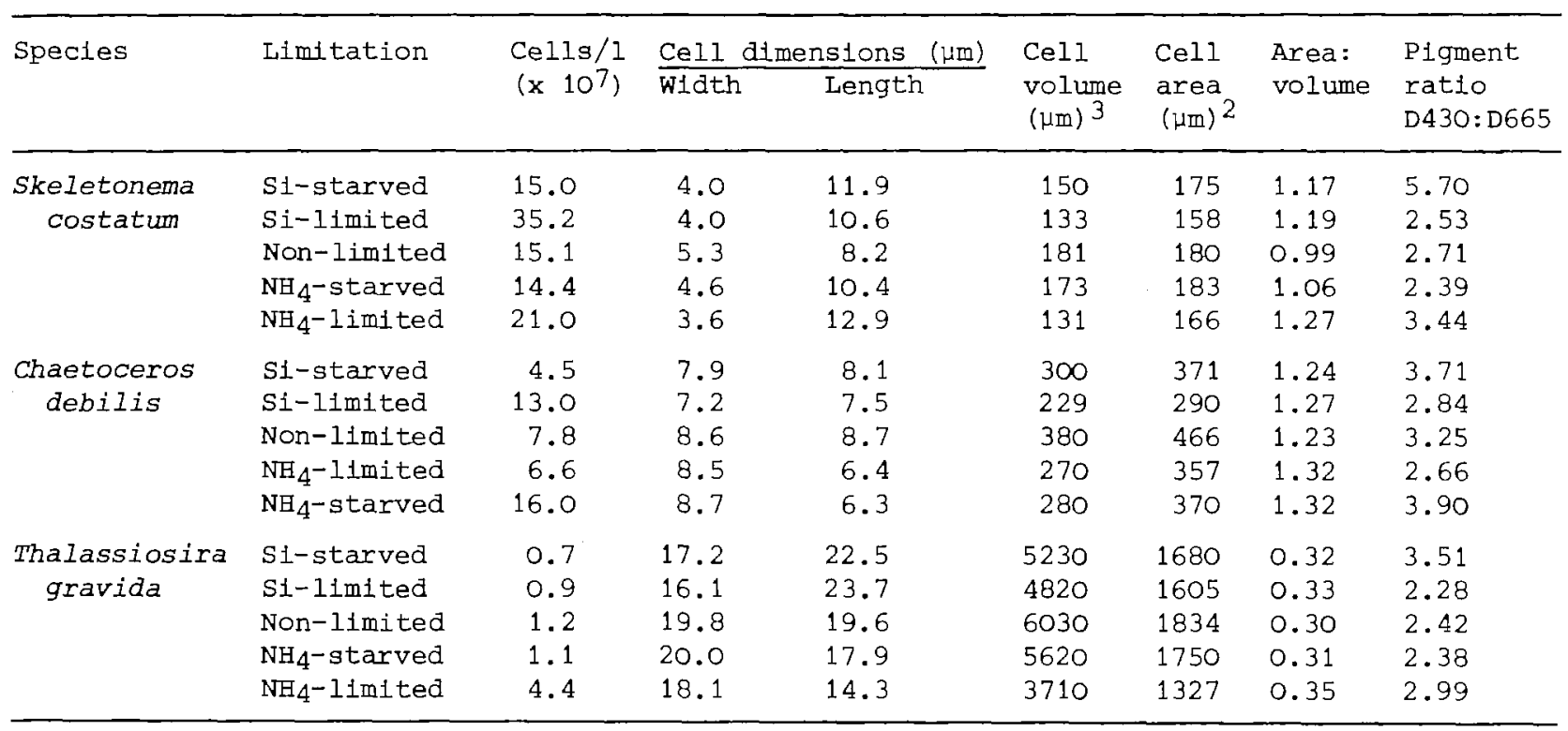

In all three species, cell volume was the largest in non-limited cells (Table 1). The reduction in cell volume in the limited and starved cells was due to decreased cell width, and this reduction was not entirely off-set by the increase in cell length which occurred in some species. The surface area:volume ratios were highest in limited and starved cells.

\section{Cellular Chemical Composition}

The cellular chemical composition of the three diatoms is expressed as ratios in Table 2 and on a volume and per cell basis in Table 3. Cells grown under no limitation are used as a standard against which an increase or decrease of a particular chemical constituent of limited or starved cells is evaluated. An examination of the differences within each species, due to a different nutrient limitation or starvation revealed the following changes in chemical composition:

(1) Cells grown under silicate starvation showed an increase in carbon, chlorophyll a, nitrogen and phosphorus and a small decrease in sillca, on a per cell volume basis. These changes resulted in an increase in the $C: N, N: S i, C:$ chloro- phyll a, and $\mathrm{N}$ :chlorophyll a ratios and a decrease in the $\mathrm{Si}: \mathrm{P}$ ratio.

(2) Under silicate limitation the cells showed a similar increase in carbon, chlorophyll a, nitrogen and phosphorus and a decrease in sil1ca per $\mathrm{\mu m}^{3}$, as observed under silicate starvation. Cellular carbon and nitrogen per volume was generally less than starved cells, and therefore the ratios $\mathrm{C}$ :chlorophyll $a$ and $\mathrm{N}$ : chlorophyll a were also lower. S1limited Skeletonema costatum and Chaetoceros debilis showed a marked decrease in the silica per unit cell volume, compared to Si-starved cells.

(3) Ammonium limitation resulted in a decrease in chlorophyll a, carbon and nitrogen per unit cell volume. The ratios N:chlorophyll $a, \mathrm{~N}: \mathrm{P}$ and $\mathrm{N}: \mathrm{Si}$ decreased, while $\mathrm{C}: \mathrm{N}$ and $\mathrm{C}$ :chlorophyll a Increased.

(4) Cells grown under ammonium starvation showed similar trends to those under ammonium limitation, except that carbon, silica, phosphorus, and nitrogen per unit cell volume were higher.

\section{Discussion}

\section{Cell Morphology}

Changes in morphology of the three species were most striking under silicate

Fig. 1. Photomicrographs of three marine diatoms grown in different nutrient environments. (A) S1limited Skeletonema costatum (2000 x); (B) non-limited S. costatum (1425 x); (C) $\mathrm{NH}_{4}$-limited $S$. costatum (1500 x); (D) S1-limited Chaetoceros debilis (1425 x); (E) non-1imited C. debilis (1040 x); (F) $\mathrm{NH}_{4}$-limited $C$. debilis $(1500 \mathrm{x}$ ); (G) S1-limited Thalassiosira gravida (1425 $\mathrm{x}$ ); (H) non-limited T. Gravida $(1425 \mathrm{x})$; (I) $\mathrm{NH}_{4}$-limited $T$. gravida (1425 $\mathrm{x}$ ); all material was living and photographed at $500 \mathrm{x}$ with phase-contrast objectives 
Table 2. Cellular chemical composttion of 3 martne diatoms expressed as ratios (by atoms), except $\mathrm{C}$ : chlorophyll $a$ and $\mathrm{N}$ :chlorophyll $a$, which are $\mu \mathrm{g}: \mu \mathrm{g}$

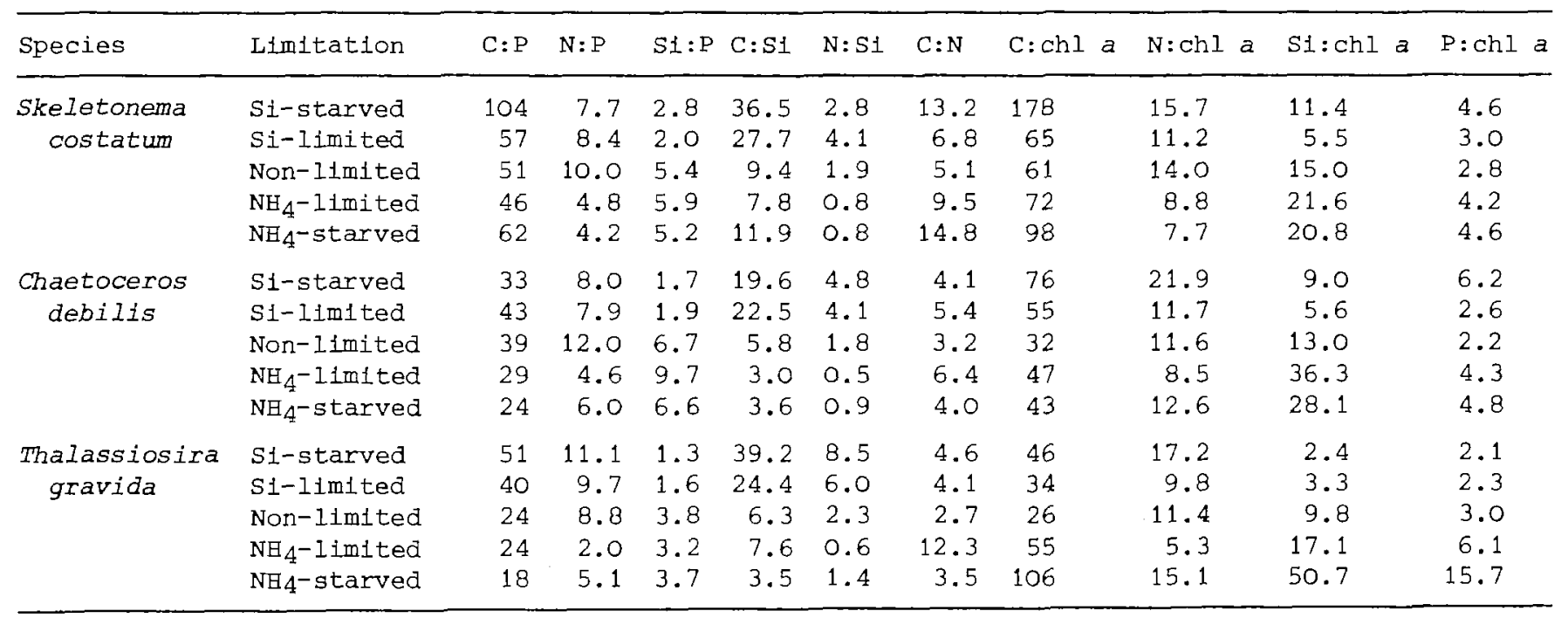

Table 3. Cellular chemical composition of 3 martne diatoms expressed on a per cell and volume basis. Values of carbon and chlorophyll a are $\mathrm{In} \mu \mathrm{g}$ and nitrogen, silica ana phosphorus are in $\mu \mathrm{g}$-at $1^{-1}$

\begin{tabular}{|c|c|c|c|c|c|c|c|c|c|c|c|}
\hline \multirow[t]{2}{*}{ Spectes } & \multirow[t]{2}{*}{ Iimitation } & \multicolumn{5}{|c|}{ Per cell $\left(x 10^{-7}\right)$} & \multicolumn{5}{|c|}{ Per $\mu \mathrm{m}^{3}\left(\mathrm{x} 10^{-10}\right)$} \\
\hline & & Chl a & $\mathrm{C}$ & $\mathrm{N}$ & S1 & $\mathrm{P}$ & Chl a & $c$ & $\mathrm{~N}$ & $\mathrm{Si}$ & $\mathrm{P}$ \\
\hline \multirow{5}{*}{$\begin{array}{c}\text { Skeletonema } \\
\text { costatum }\end{array}$} & Si-starved & 1.6 & 285 & 1.8 & 0.65 & 0.23 & 10.6 & 1900 & 12.0 & 4.33 & 1.53 \\
\hline & Si-limited & 2.0 & 130 & 1.6 & 0.39 & 0.19 & 15.0 & 977 & 12.0 & 2.93 & 1.43 \\
\hline & Non-limited & 1.4 & 85 & 1.4 & 0.75 & 0.14 & 7.7 & 470 & 7.7 & 4.14 & 0.77 \\
\hline & $\mathrm{NH}_{4}$ - IImited & 1.0 & 72 & 0.6 & 0.77 & 0.13 & 5.8 & 416 & 3.6 & 4.33 & 0.75 \\
\hline & $\mathrm{NH}_{4}$-starved & 0.9 & 96 & 0.5 & 0.67 & 0.13 & 7.4 & 733 & 4.1 & 5.11 & 0.99 \\
\hline \multirow{5}{*}{$\begin{array}{c}\text { Chaetoceros } \\
\text { debilis }\end{array}$} & Si-starved & 7.1 & 538 & 11.1 & 2.29 & 1.38 & 23.6 & 1794 & 36.9 & 7.63 & 4.60 \\
\hline & Si-limited & 5.5 & 300 & 4.6 & 1.11 & 0.58 & 24.0 & 1310 & 20.1 & 4.85 & 2.53 \\
\hline & Non-limited & 6.5 & 208 & 5.4 & 3.02 & 0.45 & 17.2 & 549 & 14.2 & 7.95 & 1.18 \\
\hline & $\mathrm{NH}_{4}-11 \mathrm{mited}$ & 2.1 & 98 & 1.2 & 2.72 & 0.28 & 7.8 & 365 & 4.7 & 10.07 & 1.04 \\
\hline & NB4-starved & 3.0 & 128 & 2.7 & 3.01 & 0.45 & 11.1 & 455 & 9.6 & 10.62 & 1.59 \\
\hline \multirow{5}{*}{$\begin{array}{l}\text { Thalassiosira } \\
\text { gravida }\end{array}$} & S1-starved & 128.0 & 5893 & 91.6 & 10.80 & 8.30 & 24.5 & 1127 & 17.5 & 2.06 & 1.59 \\
\hline & Si-limited & 109.0 & 3747 & 76.6 & 12.78 & 7.89 & 22.6 & 778 & 15.8 & 2.65 & 1.64 \\
\hline & Non-limited & 57.3 & 1520 & 46.8 & 20.00 & 5.33 & 9.5 & 252 & 7.8 & 3.32 & 0.88 \\
\hline & $\mathrm{NH}_{4}-1 \pm \mathrm{m}$ ted & 21.9 & 1216 & 8.2 & 13.36 & 4.18 & 3.8 & 216 & 1.5 & 2.38 & 0.74 \\
\hline & $\mathrm{NH}_{4}$-starved & 9.0 & 957 & 22.5 & 16.30 & 4.41 & 2.4 & 258 & 6.1 & 4.39 & 1.18 \\
\hline
\end{tabular}

limitation. A reduction in the length of the rods joining skeletonema costatum cells together, reduced setae in chaetoceros debilis, and many elongated cells with a malformed mucilagenous thread in Thalassiosira gravida, were the most prominent features observed. An increase in the pigment concentration per cell was easily detectable visually. Holmes (1966) observed an increase in the number of chromatophores in a si-starved culture of coscindadiscus sp. He suggested that when cell division was inhibited due to lack of silicate in the medium, organelle replication continued until the cell contained approximately twice its normal chromatophore and pigment complement. Coombs et al. (1967) suggested that the biprotoplastic cells observed in Si-starved cultures of Navicula pelliculosa were due to cessation of the cell cycle just after arganelle duplication occurred, and before formation of daughter cells.

The decrease in the pigment concentration per cell for all three species under ammonium limitation was strikingly visible and was the most distinguishing feature of $\mathrm{NH}_{4}$-limited cells. The larger cell vacuole was also an important characteristic of these cells. 
Even though $\mathrm{Si}-$ and $\mathrm{NH}_{4}-1$ imited cells can be identified with the light microscope, documentation of more detailed changes in the test, especially under silicate limitation, will require the use of a scanning electron microscope, and this line of research is presently being pursued. Work in this direction was initiated by Paasche (1973a), who has shown that under silicate limitation Thalassiosira pseudonana exhibited a loss of the areola pattern near the center of the valve. Determining the extent to which valve patterns may be changed under different limitations may prove important in taxonomic identiflcation of some genera. For example, in freshwater studies, the diatom cyclotella woltereckif was found to be the silica-deficient form of $c$. pseudostelligera (Belcher et al., 1966).

There was a small increase in the surface-to-volume ratio of cells grown under limitation or starvation (Table 1). but this may be an important adaptation to aid cells in taking up nutrients when they are growing in nutrientlimited or deficient conditions. For the tropical marine diatom coscinodiscus pavillardii, Findlay (1972) found a good correlation between relative growth rate and surface:volume, with the highest growth rate occurring at the largest surface:volume ratio.

\section{Cellular Chemical Composition}

The changes in the chemical composition of each diatom species are examined by considering the effect of the five different nutrient past histories (ammonium or silicate limitation, ammonium or silicate starvation, and no limitation) on 11 chemical composition ratios, carotenoid:chlorophyll a, C:chlorophyll a, $N$ : chlorophyll a, S1: chlorophylla, P:chlorophyll a, C:N, C:S1, C:P, Si:P, N:P and $\mathrm{N}: \mathrm{Si}$. Data from the 11terature on the effect of nitrogen and silicon limitation or deficiency on cellular chemical composition of marine diatoms have been summarized in Table 4 to facilitate comparison with results from this study.

\section{Pigment Ratio}

The pigment ratio $\mathrm{D}_{430}: \mathrm{D}_{665}$ is roughly proportional to the carotenold:chlorophyll a ratio (Margalef, 1968). It varies considerably, between 2 and 8 , and higher ratios are indicative of older cultures of nutrient deficiency.

The plgment ratio under silicate or ammonium limitation was slightly lower than for non-limited cells (Table 1).
However, starvation clearly resulted in higher ratios, which could be a result of cessation of chlorophyll a synthesis or an increased rate of chlorophyll degradation. Healey et al. (1967) examined pigment changes durlng silicon starvation of Navicula pelliculosa and found that chlorophyll a synthesis ceased in 5 to $7 \mathrm{~h}$ of silicon starvation, but that diadinoxanthin (a carotenoid) and I1pid synthesis continued.

\section{C:Chlorophy11 a}

The C:chlorophyll a ratio has been wideIy measured due to 1 ts usefulness in estimating particulate carbon from chlorophy 11 measurements and in determining assimilation ratios. This ratio generally varies by over a Eactor of 2 with healthy, natural populations ranging from 20 to about 60 . A mean value of 40 is often used in calculations, the value obtained by Lorenzen (1967) for healthy populations in an upwelling area. The range of C:chlorophyll a values (26 to 61) for the three diatoms in this study under no nutrient limitation are within this range.

The C:chlorophyll a ratios under silicate starvation and limitation were higher than non-limited cells, due to the increased carbon per cell. S1starved cells had the highest carbon per cell and therefore the highest $c: c h l o r o-$ phyll a ratio. This observation can be explained by the results of Werner (1966) and Coombs et al. (1967), who demonstrated that carbohydrate and lipld synthesis continue for a longer time than protein and chlorophyll a synthesis under silicon starvation.

Under ammonium starvation and imitation, the c:chlorophyll a ratio was also higher than for non-limited cells; however, in this case it was due to a decrease in the chlorophyl1 a/cell. C:chlorophyll a for $\mathrm{NH}_{4}$-starved skeletonema costatum and Thalassiosira gravida was higher than for $\mathrm{NH}_{4}-1$ imited cells. Several studies corroborate these results. Hobson and Pariser (1971) found that the $\mathrm{C}: \mathrm{chlo}-$ rophyll a ratio increased from 4 to 10 times when $T$. pseudonana was $\mathrm{N}$-starved, and they reported values as high as 200. They stated that the hlgh values were due to a decrease in chlorophyll a/cell and, after $160 \mathrm{~h}$ of starvation, due to an increase in C/cell. Holm-Hansen et al. (1968) found that the ratio for healthy S. costatum increased from 70 to about 200 under $\mathrm{N}$-deficient condttions. Recently, Eppley and Renger (1974) found that C: chlorophyll a increased from 28.7 to 91.4 as the degree of nitrogen limita- 


\begin{tabular}{|c|c|c|c|c|c|c|c|}
\hline Limitation & Spectes & $D\left(\mathrm{~h}^{-1}\right)$ & $\mathrm{C}: \mathrm{N}$ & $C: S I$ & $C: P$ & $\begin{array}{l}\text { C: chloro- } \\
\text { phyll a }\end{array}$ & $N: S 1$ \\
\hline N1trate & $\begin{array}{l}\text { Cyclotella } \\
\text { nana }\end{array}$ & $0.077-0.009$ & $7.7-20.0$ & - & - & $76-500$ & - \\
\hline N1trogen & $\begin{array}{c}\text { Chaetoceros } \\
\text { debilis }\end{array}$ & $0.097-0.008$ & $9.8-12.9$ & - & - & $57.4-53.6$ & - \\
\hline Nitrogen & $\begin{array}{c}\text { Thalassiosira } \\
\text { pseudonara }\end{array}$ & $0.041-0.008$ & $5.7-14.8$ & - & $63.4-90.5$ & $28.7-91.4$ & - \\
\hline Amon1um & $\begin{array}{c}\text { Skeletonema } \\
\text { costatum }\end{array}$ & $0.110-0.042$ & - & - & - & - & $3.8-0.6$ \\
\hline Nitrogen & $\begin{array}{l}\text { Skeletonema } \\
\text { costatum }\end{array}$ & $o^{a}$ & $4.8-9.4$ & - & - & $70-220$ & - \\
\hline N1trate & $\begin{array}{c}\text { Thalassiostra } \\
\text { fluviatilis } \\
\text { Thalassiosira } \\
\text { pseudonana }\end{array}$ & $\begin{array}{l}0^{a} \\
o^{a}\end{array}$ & $\begin{array}{l}6.3-12.0 \\
4.8-10.0\end{array}$ & $\begin{array}{l}- \\
-\end{array}$ & - & $\begin{array}{c}18-26 \\
111-200\end{array}$ & - \\
\hline S1licate & $\begin{array}{l}\text { Skeletanems } \\
\text { costatum }\end{array}$ & $0.061-0.035$ & - & $\rightarrow$ & - & - & $3.3-4.1$ \\
\hline sillcate & $\begin{array}{c}\text { Skeletonema } \\
\text { costatum }\end{array}$ & $0.086-0.022$ & - & - & - & - & $3.3-5.7$ \\
\hline
\end{tabular}

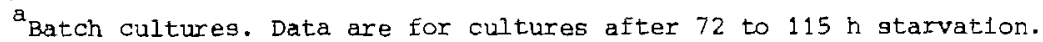

tIon was increased in a chemostat (Table 4).

\section{$\mathrm{N}:$ Chlorophyl1 a}

$\mathrm{N}$ : chlorophyll a ratios for Si-starved cells were higher than for non-limited and si-limited cells, primartly due to the increase in $\mathrm{N} / \mathrm{cell}$ under silicate starvation. For Si-limited skeletonema costatum and Thalassiosira gravida the $\mathrm{N}$ :chlorophyll a was lower than for non-limited cells due to the increased chlorophyll a/cell. In previous chemostat studies, Harrison et al. (1976) found that chlorophyll a/cell increased and consequently $\mathrm{N}$ : chlorophyll a decreased from 75 to 11 with increasing silicate limitation (Table 4 ).

Ammonium-limited cells clearly exhibited the lowest $\mathrm{N}$ : chlorophyll a ratio of all nutrient conditions studied, indicating that the $\mathrm{N}$ :chlorophyll a ratio would be a sensitive indicator of nitrogen limitation. Both chlorophyll a/cell and $\mathrm{N} /$ cell decreased, however, the decrease in $\mathrm{N} / \mathrm{cell}$ was much greater, and therefore accounted for most of the decrease in the $\mathrm{N}$ : chlorophyll a ratio. For $\mathrm{NH}_{4}$-starved celis, the $\mathrm{N}$ : chlorophyll a ratio showed no consistent pattern for the three species, since the amount of decrease in the $\mathrm{N}$ :cell ratio was variable.
In chemostat studies of nitrogen 11mitation, Caperon and Meyer (1972) showed that the $\mathrm{N}$ : chlorophyll a ratio was relatively constant $(\sim 12.9)$ for dilution rates from 0.077 to $0.040 \mathrm{~h}^{-1}$. The rat1o increased to 35 only at dilution rates lower than $0.040 \mathrm{~h}^{-1}$. Similarly, Bienfang (1975) found that $\mathrm{N}$ : chlorophyll a was also statistically invariant for dilution rates over the range 0.045 to $0.076 \mathrm{~h}^{-1}$ for the green flagellate Dunaliella tertiolecta. For dilution rates less than $0.04 \mathrm{~h}^{-1}$, Thomas and Dodson (1972) and Eppley and Renger (1974) found that $\mathrm{N}$ : chlorophyll a increased with increasing nitrogen limitation (1.e., lower dilution rate; Table 4). Recently, Harrison et al. (1976) showed that for Skeletonema costatum at a higher dilution rate range from 0.11 to $0.042 \mathrm{~h}^{-1}$, $\mathrm{N}$ : chlorophyll a decreased due to the decrease in $\mathrm{N} / \mathrm{cell}$, as nitrogen limitation increased.

\section{S1:Chlorophyll a}

This ratio was always lower for Silimited and starved celis than for nonlimited cells, with si-limited cells having the lowest ratio by a factor of 3 . The large decrease in this ratio was due to decreased $S 1 / \mathrm{cell}$ and increased chlorophyll a/cell. For $\mathrm{NH}_{4}$-limited or starved cells 51 :chlorophyll a was al- 
Table 4 (continued)

\begin{tabular}{|c|c|c|c|c|c|}
\hline$N: P$ & $\begin{array}{l}\text { N:chloro- } \\
\text { phyll a }\end{array}$ & $\mathrm{S} 1: \mathrm{P}$ & $\begin{array}{l}\text { Si:chloro- } \\
\text { phyll a }\end{array}$ & $\begin{array}{l}\text { P:chloro- } \\
\text { phyll a }\end{array}$ & Source \\
\hline- & $11.7-35.6$ & - & - & - & Caperon and Meyer (1972) \\
\hline- & $2.9-4.8$ & - & - & - & Thomas and Dodson (1972) \\
\hline $9.7-6.4$ & $5.8-7.5$ & - & - & $1.2-2.6$ & $\begin{array}{l}\text { Eppley and Renger (1974); } \\
\text { Perry (1976) }\end{array}$ \\
\hline $15 \cdot 2-5.1$ & $28.9-5.6$ & $4.0-8.8$ & $22.7-21.0$ & $6.1-2.6$ & Harrison et al. (1976) \\
\hline- & $11.5-20.0$ & - & - & - & Holm-Hansen et al. (1968) \\
\hline- & $2.9-2.2$ & - & - & - & Hobson and Partser (1971) \\
\hline- & $23.3-20.0$ & - & - & - & Hobson and Pariser (1971) \\
\hline $10.0-6.1$ & - & $3.0-1.5$ & - & - & Davis (1973) \\
\hline $10.0-9.8$ & $74.6-10.7$ & $3.0-1.7$ & $43.9-3.7$ & $19.2-2.5$ & Harrison et al. (1976) \\
\hline
\end{tabular}

ways higher than for non-limited cells due to the decrease in chlorophyll a/cell. Harrison et al. (1976) found that, for Skeletanema costatum, Si:chlorophyll a decreased from 43.9 to 3.7 with increasing silicate limitation 1 n a chemostat, while the ratio remalned nearly constant $(-21)$ under ammonium limitation (Table 4).

\section{P : Chlorophyl1 a}

For Si-limited and starved cells, the ratio was similar to that for non-limited cells because both chlorophyll a and $P / c e l l$ increased under silicate limitation and starvation. The ratio was always higher for $\mathrm{NH}_{4}$-limited and starved cells than for non-limited cells, with $\mathrm{NH}_{4}$-starved cells being the highest; this was due to a decrease in chlorophyll a/cell. Chemostat studies have shown that $\mathrm{P}$ :chlorophyll a was relatively constant when dilution rates were less than $0.054 \mathrm{~h}^{-1}$, but the ratio increased when dilution rates were greater than $0.054 \mathrm{~h}^{-1}$, for both silicate and ammonlum limitation (Harrison et al., 1976). Perry (1976) found that P:chlorophyll a increased with increasing nitrogen limitation for dilution rates less than $0.04 \mathrm{~h}^{-1}$ (Table 4).

$\mathrm{C}: \mathrm{N}$

The range of $\mathrm{C}: \mathrm{N}$ for the non-limited cultures $1 \mathrm{n}$ our study was from 2.7 to 5.1 .
This is somewhat lower than the expected 106C: $16 \mathrm{~N}$ or $6.6: 1$ ratio (Redfield et al., 1963). For non-limited cultures of Chaetoceros sp. and skeletonema costatum, Parsons et al. (1961) found $C: N$ ratios of 6.6 and 5.3 , respectively.

Silicate limitation or starvation increased the $\mathrm{C}: \mathrm{N}$ ratio. Th1s increase was primarily due to the large increase in $\mathrm{C} / \mathrm{cell}$, even though $\mathrm{N}$ :cell also $1 \mathrm{n}-$ creased. These observations agree with those made by werner (1966) on Si-starved cyclotella cryptica. He observed that proteln synthesis was blocked earlier than carbohydrate synthesis when the cells became Si-starved.

Ammonium limitation or starvation also Increased the $\mathrm{C}: \mathrm{N}$ ratio, primarily due to the decrease in $\mathrm{N}:$ cell. Hobson and Pariser (1971) found that nitrogen starvation 1ncreased the $C: N$ ratio in Thalassiosira pseudonana from 4.8 to 10 . They suggested that $\mathrm{N}$-starved cells continue to synthesize organic matter deflclent in nitrogen and rich in carbohydrates. In batch-culture experiments, Conover (1975) found that the $C: N$ ratio increased from 5 to about 200 as a culture of $T$. fluviatilis became senescent. In four other studies (Caperon and Meyer, 1972; Thomas and Dodson, 1972; Eppley and Renger, 1974; Blenfang, 1975) using $\mathrm{N}$-limited chemostat cultures of 
various phytoplankton species, the C:N ratio increased by about two-fold with increasing nitrogen limitation (Table 4 ).

\section{$\mathrm{C}: \mathrm{Si}$}

The ratio for si-limited and starved cells was 3 to 15 times higher than for non-limited cells, and the Si-starved ratio was higher than for silicate limitation (except for Chaetoceros debilis). The increase was due to a decrease in $\mathrm{Si} / \mathrm{cell}$ and an increase in $\mathrm{C} / \mathrm{cell}$. Under ammonium limitation and starvation, the C:S1 ratlo was variable but similar to the ratio for non-limited cells.

\section{$\mathrm{C}: \mathrm{P}$}

Under silicate limitation and starvation, the $C: P$ ratio was higher than for nonlimited celis. The ratio was higher for Si-starved cells than for Si-limited cells, due to the larger increase in $\mathrm{C} / \mathrm{cell}$ compared to the increase in $\mathrm{P} /$ cell. Chaetoceros debilis deviated from this latter trend because of the factor of 3 increase in $\mathrm{P} / \mathrm{cell}$, resulting in a lower C:P ratio.

The $\mathrm{C}: \mathrm{P}$ ratio under ammonium limitation or starvation was vartable, but simllar in magnitude to non-limited cells. Perry (1976) found that the ratio increased as the degree of nitrogen limitation increased in a chemostat (Table 4).

\section{Si:P}

For the non-limited cultures in our study, the Si:P ratio ranged from 3.8 to 6.7. In all cases, silicate limitation or starvation resulted in a reduction in this ratio. This was due to decreased Si/cell under silicate limitation and partially due to increased $\mathrm{P}$ :cell under silicate starvation. Chemostat studies with Si-limited Skeletonema costatum showed that the Si:P ratio decreased from 3 to 1.7 as the degree of silicate limitation increased (Harrison et al., 1976).

Under ammonium limitation or starvation, the Si:P ratio was similar to the ratio for non-limited cells, since there was no excess accumulation of phosphate as was observed under sillcate starvation. In earlier chemostat studies with Skeletonema costatum, $\mathrm{Si}: \mathrm{P}$ was observed to increase at low dilution rates in an $\mathrm{NH}_{4}$-limited chemostat, due to a decrease in $\mathrm{P} / \mathrm{cell}$ (Harrison et al., 1976).

$N: P$

The range of $\mathrm{N}: \mathrm{P}$ for the non-limited cultures was 8.8 to 12.0 . Values of $\mathrm{N}: \mathrm{P}$ for laboratory cultures of a number of phytoplankton specles have been measured and found to vary considerably. In general, the ratio is usually less than the accepted value for the composition of seawater of 15 or 16:1 (Corner and Davies, 1971). Parsons et al. (1961) grew a number of species in batch culture, and found for Skeletonema costatum and chaetoceros sp. ratios of 7.7 and 8.3 , respectively.

Under silicate limitation or starvation, the ratio was similar to the ratio for.non-limited cells. This is consistent with the findings in other Silimited chemostat studies where the $\mathrm{N}: \mathrm{P}$ ratio was found to remain constant at about 10 when the silicate limitation increased (Harrison et al., 1976).

The $\mathrm{N}: \mathrm{P}$ ratio was consistently lower under ammonium limitation or starvation, due to the decreased $\mathrm{N} / \mathrm{cell}$. Harrison et al. (1976) and Perry (1976) have shown that the N:P ratio decreases with increasing nitrogen limitation in chemostat cultures and that this decrease can be as high as 3-fold, from 15 to 5 (Table 4).

\section{$\mathrm{N}: \mathrm{Si}$}

Values of this ratio showed the greatest difference between the two nutrient limitations, ammonium and silicate. The ratio was generally 2 to 3 times higher for si-limited and starved cells and 2 to 3 times lower for $\mathrm{NH}_{4}$-limited and starved cells than for non-limited cells. The N:Si ratio has been shown to increase from 3.3 to 5.7 with increasing silicate limitation in chemostat cultures of skeletonema costatum, and the rat10 decreased from 3.8 to 0.58 with increasing ammonium limitation (Harrison et al., 1976).

In summary, comparison of cellular chemical composition of nutrient-limited and starved cells on a per unit cell volume basis indicates that nutrientlimited cells showed a greater modification in cellular chemical composition than nutrient-starved cells. $\mathrm{NH}_{4}$-limited cells had lesser amounts of carbon, nitrogen, sillca, phosphorus and generally chlorophyll a per $\mu^{3}$ than did $\mathrm{NH}_{4}{ }^{-}$ starved cells. Similarly, Si-limited cells had lower amounts of carbon, phosphorus and generally silica per $\mathrm{mm}^{3}$ than Si-starved cells. This conclusion is also borne out by the fact that the greatest changes in morphology occurred in $\mathrm{NH}_{4}^{-}$or Si-limited cells. These observations can be explained by the fact that after cells exhaust a particular nutrient from the medium, cell division ceases after one or two more cell divi- 
sions and thus the modification that does occur in nutrient-starved cells, must occur during these one or two divisions and for a short period after cell division ceases. Cells grown in chemostats under nutrient-limitation go through many $(>10)$ generations before a steady state is obtained and modification in chemical composition is complete. Therefore, in laboratory studies to determine the full range of chemlcal composition for one species under one nutrient limitation, nutrient-limited rather than nutrient-starved cells should be used, along with non-limited cells.

\section{Ecological Significance}

In addition to confounding taxonomic studies, changes in morphology induced by silicate or ammonium limitation may also increase sinking rates. The reduction in the length of the setae in Chaetoceros debilis and in the length of the rods joining the cells of skeletonema costatum that occurred under silicate l1mitation have previously been shown to increase sinking rates (Smayda and Boleyn, 1966; Smayda, 1970). These observations suggest that the sinking rate of cells under silicate limitation may be higher than under ammonium limitation, due to the substantial modification and reduction in extensions of the frustule that do not occur under ammonium limitation. Future investigations in this direction are needed.

The photomicrographs of the cells (Fig. 1) suggest that it is possible to visually assess the nutritional status of marine diatoms by correlating visual symptoms induced by limitation or starvation with the particular element in short supply such as nitrogen or silicon. The usefulness of this approach in field studies will depend partially on the magnitude of the sinking rates and the depth of the thermocline. Titman and Kilham (1976) have shown that sinking rate increases substantially, shortly after the on-set of phosphate starvation, and it begins to decrease about $12 \mathrm{~h}$ after phosphate enrichment. Due to this reasonably rapid adjustment of sinking rate by cells, it is possible that cells could quickly sink into high-nutrient, deep water (where recovery from limitation would begin) before nutrientdeficient symptoms are well developed.

The chemical composition of thalassiosira pseudonana grown in a chemostat under phosphorus or nitrogen limitation has been compared and the effect on ratios evaluated (Perry, 1976). Perry suggested that ratios which differed by a factor of 5 or more could be considered useful diagnostic parameters in determining nutritional status of phytoplankton. Based on this criterton, only one ratio, N:S1, would be useful in distinguishing between S1- and N-limited phytoplankton. This ratio was similar for all three species, with an average value of 5.1 for Si-starved or limited, 2.0 for nonlimlted, and 0.8 for $\mathrm{NH}_{4}$-starved or $11 \mathrm{~m}-$ ited. Other ratios including C:Si, N:P, S1:P and Si:chlorophyll a were different by a factor of at least 2 . The 5 ratios that would be least useful in distinguishing between silicate or nitrogen limitation were C:N, C:P, C:chlorophyll a, N:chlorophyll $a$ and $\mathrm{P}$ :chlorophyll a. Generally, these ratios increased for both silicate and ammonium limitation, but for different reasons. (The N:chlorophyll a ratio under ammonium limitation was an exception.) In all cases, the change in these 5 ratios was small and could not be easily detected using natural phytoplankton populations.

Due to the problems of measuring the chemical composition of living phytoplankton in the ocean, the nutritional status of phytoplankton in the field is best studied by comblning a number of approaches. These are: measuring one or two of the more sensitive chemical composition ratios, visually examining the cells for symptoms of certain nutrient deficiencies, and measuring uptake $\mathrm{ki}-$ netics on a time-series basis.

Acknowledgements. This research was supported by National Science Foundation Grants GB 6394, GA 31093 and GB 20182. The AutoAnalyzer was maintalned by G. Friederich, and D. Harmon assisted in data analysis and sampling. The CHN analyzer was maintained by R. Feller and $J$. vidal.

\section{Literature Cited}

Belcher, J.H., E.M.F. Swale and J. Heron: Ecological and morphological observations on a population of Cyclotella pseudostelligera Hustedt. J. Ecol. 54, 335-340 (1966)

Bienfang, P.K.: Steady state analysis of nitrateammontum assimilation by phytoplankton. Limnol. Oceanogr. 20, 402-411 (1975)

Blasco, D.: Estudio de las variaciones de la relación fluorescencia in vivo/chlorofila a, y su aplicación en oceanografia. Influencia de la limitacion de diferentes nutrientes, efecto del dia y noche $y$ dependencia de la especie estudiada. Investigatión pesq. 37 , 533-536 (1973)

Braarud, T.: On varlations in form of Sceletonema costatum and their bearing on the supply 
of silica in cultures of diatoms. Nytt Mag. Naturvid. (B) $86,31-44$ (1948)

Busby, W.F. and J. Lewin: Silicate uptake and silica shell formation by synchronously dividing cells of the diatom Navicula pelliculosa (Brëb.) Hilse. J. Phycol. 3, 127-131 (1967)

Caperon, J. and J. Meyer: Nitrogen-limited growth of martne phytoplankton. I. Changes in population characteristics with steady-state growth rate. Deep-Sea Res. 19, 601-618 (1972)

Collos, Y. and J. Lewin: Blooms of surf-zone diatoms along the coast of the Olymplc Peninsula, Washington. 7. Variations of the carbonto-nitrogen ratio in fleld samples and laboratory cultures of Chaetoceros armatum. Iimnol. Oceanogr. 21, 219-225 (1976)

Conover, S.A.M.: Partitioning of nitrogen and carbon in cultures of the marine dlatom Thalassiosira fluviatilis supplled with nitrate, ammonlum or urea. Mar. Biol. 32, 231246 (1975)

Conway, H.I.: The uptake and assimilation of inorganic nitrogen by skeletonema costatum (Grev.) Cleve, $125 \mathrm{pp}$. Ph.D. dissertation, University of Washington, Seattle 1974

- and P.J. Harrison: Marine diatoms grown in chemostats under silicate or ammonium limitation. IV. Transient response of Chaetoceros debilis, Skeletonema costatum, and Thalassiosira gravida to a single addition of the limiting nutrient. Mar. Biol. 43, 33-43 (1977)

- - and C.O. Davis: Marine diatoms grown in chemostats under silicate or ammonium limitation. II. Transient response of Skeletonema costatum to a single addition of the limiting nutrient. Mar. Biol. 35, 187-199 (1976)

Coombs, J., W.M. Darley, O. Holm-Hansen and B.E. Volcan1: Studies of the biochemistry and fine structure of sillca shell formation in diatoms. Chemical composition of Navicula pelliculosa during silicon-starvation synchrony. Pl. Physiol., Lancaster 42, 1601-1606 (1967)

Corner, E.D.S. and A.G. Davies: Plankton as a factor in the nitrogen and phosphorus cycles in the sea. Adv. mar. Biol. 9, 101-204 (1971)

Davis, C.O.: Effects of changes in light intensity and photoperiod on the silicate-limited continuous culture of the marine diatom Skeletonema costatum (Grev.) Cleve, $122 \mathrm{pp}$. Ph.D. dissertation, University of Washington, Seattle 1973

- Continuous culture of marlne diatoms under silicate limitation. II. Effect of light intensity on growth and nutrient uptake of Skeletonema costatum. J. Phycol. 12, 291-300 (1976)

-, P.J. Harrison and R.C. Dugdale: Continuous culture of marlne diatoms under silicate limitation. I. Synchronized life cycle of Skeletonema costatum. J. Phycol. 9, 175-180 (1973)

Droop, M.R.: The nutrient status of algal cells in continuous culture. J. mar. biol. Ass. U.K. 54, 825-855 (1974)

Eppley, R.W. and E.H. Renger: Nitrogen assimilation of an oceanlc diatom in nitrogen-limited continuous culture. J. Phycol. 10, 15-23 (1974)

Findlay, I.W.O.: Effects of external factors and cell size on the cell division rate of a marine dlatom Coscinodiscus pavillardif Forti. Int. Revue ges. Eydrobiol. 57, 523-533 (1972)

Fuhs, G.W.: Phosphorus content and rate of growth in the diatoms Cyclotella nana and Thalassiosira fluviatilis. J. Phycol. 5, 312321 (1969)

-, S.D. Demmerle, E. Canelli and M. Chen: Characterization of phosphorus-limited algae. In: Nutrients and eutrophication, pp 113-132. Ed. by G.E. Llkens. Lawrence, Kansas: Allen Press Inc. (Spec. Symp. Am. Soc. Limnol. Oceanogr., No. 1) 1972

Gulllard, R.R.L. and J.H. Ryther: Studies of marine plankton diatoms. I. Cyclotella nana (Hustedt) and Detonula Confervacea (Cleve). Gran. Can. J. Microblol. 8, 229-239 (1962)

Harrison, P.J.: Continuous culture of the marine diatom Skeletonema costatum (Grev.) Cleve, under silicate limitation, 140 pp. Ph.D. dissertation, University of Washington, Seattle 1974

-, H.I. Conway and R.C. Dugdale: Martne diatoms grown in chemostats under silicate or ammonium limitation. I. Cellular chemical composition and steady-state growth kinetics of skeletonema costatum. Mar. Biol. 35, 177-186 (1976)

Healey, P., J. Coombs and B.\&. Volcan1: Changes in plgment content of Navicula pelliculosa in silicon-starvation synchrony. Arch. Mikrobiol. 59, 131-142 (1967)

Hobson, L.A. and R.J. Pariser: The effect of inorganic nitrogen on macromolecular synthesis by Thalassiosira fluviatilis Hustedt and Cyclotella nana Hustedt grown in batch culture. J. exp. mar. Biol. Ecol. 6, 71-78 (1971)

Holmes, R.W.: Solar radiation, gubmartne daylight and photosynthesis. In: Treatise on marine ecology and paleoecology. Vol. 1. Ecology, pp 109-128. Ed. by J.W. Hedgpeth. New York: Geological Soctety of America 1957. (Mem. geol. Soc. Am. No. 67)

- Light microscope observations on cytological manffestations of nitrate, phosphate, and sillcate deficlency in four marine centric diatoms. J. Phycol. 2, 136-140 (1966)

Holm-Hansen, O., W.E. Sutcliffe (Jr.) and J. Sharp: Measurement of deoxyribonucleic acid In the ocean and its ecological significance. Limnol. Oceanogr. 13, 507-514 (1968)

Jorgensen, E.G.: The adaptation of plankton algae. II. Aspects of the temperature adaptation of skeletonema costatum. Physlologia PI. $21,423-427$ (1968)

Ketchum, B.H. and A.C. Redfield: Some physlcal and chemical characterlstics of algae growth in mass culture. J. cell. comp. Physiol. 33, 281-299 (1949)

Kilham, S.S.: K1netics of silicon-limited growth in the freshwater diatom Asterionella formosa. J. Phycol. 11, 396-399 (1975) 
Lorenzen, C.J.: Carbon/chlorophyl1 relationships in an upwelling area. Limnol. Oceanogr. 13, 202-204 (1967)

Margalef, R.: Perspectives in ecological theory, $111 \mathrm{pp}$. Chicago: The Untversity of Chicago Press 1968

Paasche, E.: Silicon and the ecology of marine plankton diatoms. I. Thalassiosira pseudonana (Cyclotelia nana) grown in a chemostat with silicate as limiting nutrient. Mar. Biol. 19, $117-126$ (1973a)

- The influence of cell size on growth rate, silica content and some other properties of four marine diatom species. Norw. J. Bot. 20, 197-204 (1973b)

- Growth of the plankton diatom Thalassiosira nordenskioeldii cleve at low sillcate concentrations. J. exp. mar. B1ol. Ecol. 18, 173183 (1975)

Parsons, T.R., K. Stephens and J.D.H. Strickland: On the chemical composition of eleven species of marine phytoplankters. J. Fish. Res. Bd Can. 18, 1001-1016 (1961)

Perry, M.J.: Phosphate utilization by an oceanic diatom in phosphorus-limited chemostat culture and in the oligotrophic waters of the central north Pacific. Limnol. Oceanogr. 21 , 88-107 (1976)

Pugh, P.R.: Varlations in the biochemical composition of the diatom Coscinodiscus eccentricus with culture age and salinity. Mar. Biol. $33,195-205$ (1975)

Redfleld, A.C., B.H. Ketchum and F.A. Richards: The influence of organisms on the compos1tion of sea-water. In: The sea, Vol. 2. pp
26-77. Ed. by M.N. Hill. New York: Wiley Interscience 1963

Smayda, T.J.: The suspension and sinking of phytoplankton in the sea. Oceanogr. mar. biol. A. Rev. 8, 353-414 (1970)

- and B.J. Boleyn: Experimental observations on the flotation of marine diatoms. II. Skeletonema costatum and Rhizosolenia setigera. Limnol. Oceanogr. 11, 18-34 (1966)

Strickland, J.D.H., O. Holm-Hansen, R.W. Eppley and R.J.Linn: The use of a deep tank in plankton ecology. I. Studies on the growth and composition of phytoplankton crops at low nutrient levels. Limnol. Oceanogr. 14, 23-34 (1969)

Thomas, w. B. and A.N. Dodson: On nitrogen deficiency in tropical Pacific oceanic plankton. II. Photosynthetic and cellular characteristics of a chemostat grown diatom. Iimnol. Oceanogr. 17, 515-523 (1972)

Titman, D. and P. K1lham: Sinking in freshwater phytoplankton: some ecological implications of cell nutrient status and physical mixing processes. Limnol. Oceanogr. 21, 409-417 (1976)

Werner, D.: Die Kieselsaure in Stoffwechsel von Cyclotella cryptica, Reiman, Lewin and

Guillard. Arch. Mikrobtol. 55, 278-308 (1966)

Dr. Paul J. Harrison Institute of Oceanography and Department of Botany Universtty of British Columbia Vancouver V6T 1W5, British Columbia Canada

Date of final manuscript acceptance: Apr11 15, 1977. Communicated by M.R. Tripp, Newark 